\title{
A party within a party posing as a movement? Momentum as a Movement Faction
}

James Dennis

School of Film, Media and Communication, University of Portsmouth

\begin{abstract}
This article examines how the UK political organization Momentum uses social media within its campaigning. Drawing on a mixed-method research design, combining interviews with activists in Portsmouth and discourse analysis of content posted on Facebook and Twitter, this article tests whether the leadership provides meaningful influence for members. At the national level, there is little evidence of Momentum fulfilling its "people-powered" vision. Instead, supporters are instructed to undertake tasks at the direction of the leadership. However, this is not a straightforward case of controlled interactivity. The local group in Portsmouth is semiautonomous, providing member-driven advocacy that is coordinated through a Facebook Group. By using social media to underpin different organizational norms and campaigning tactics at different spatial levels, Momentum represents a "movement faction".
\end{abstract}

Keywords: activism; campaigning; engagement; Labour Party; Momentum; political parties; social movements; social media

Forthcoming in Journal of Information Technology and Politics, 2020

“Author's Accepted Manuscript," December 3, 2019, for UK Research Excellence Framework eligibility. Please read and cite the final copyedited and typeset version of this article, which can be found here: https:/www.tandfonline.com/loi/witp20 
With a reported 40,000 members, 200,000 supporters, and over 170 local groups across the UK, Momentum, the political activist group founded in the wake of Jeremy Corbyn's rise to leader of the Labour Party, has become an insurgent force in British politics (Cowburn, 2017; Momentum, 2018d). ${ }^{1}$ Scholars have cited the group's digital campaigning tactics when seeking to understand the unexpected gains for Labour in the 2017 UK general election (Dommett and Temple, 2018; McDowell-Naylor, 2019; Rhodes, 2019). However, outside of this electoral focus, we know very little of the group's organizational form and how social media is used within its day-to-day political campaigning. Although Momentum describes itself as a "peoplepowered movement" (Momentum, 2018a), using digital media to support social movement style organizing, several prominent members of the Labour Party have questioned the legitimacy of such claims. For instance, in 2016, the then Labour Party MP Chuka Umunna argued that "Momentum is a party within a party posing as a movement" (Sparrow et al., 2016), suggesting a more hierarchical form of decision making.

Drawing on a mixed-method research design, combining semi-structured interviews with organizers, members, and supporters of Momentum and a descriptive discourse analysis of content posted on public-facing Facebook and Twitter pages, I analyze this debate, examining how Momentum uses social media within its activism. I explore how members and supporters use these tools to engage with the leadership. Is power diffused to grassroots members using these platforms (Dennis, 2018; Karpf, 2016), or does the group adopt the tactics of political parties online, instructing members and supporters to complete specific tasks based on a hierarchically-driven agenda (Kreiss, 2012; Stromer-Galley, 2014)? Furthermore, by conducting ethnographic research on a local Momentum group in Portsmouth, I analyze the differences that exist in these tactics, if any, at the national level and the local level.

In doing so, I seek to observe the organizational dynamics of Momentum. While frequently presented as a pioneer in the advocacy space due to its digital tactics (Cowburn, 2017; Rees, 2017), there is a lack of clarity regarding what kind of political organization Momentum is. This is due to the conflicting nature of the group's campaigning, as it draws upon a range of engagement repertoires in its activism, where repertoires refer to the participatory tactics and structural form adopted by a political group (Chadwick, 2007: 285). By lobbying the government to change policy (Momentum, 2018c; 2018j) and by taking part in demonstrations, such as the march organized in opposition to President Donald Trump's first official visit to the UK, Momentum frequently appears to act as a pressure group. The group's participation in internal elections within the Labour Party suggests, however, that they also resemble a party-affiliated faction, competing with other groups like Open Labour and Progress 
for influence. Such structural fluidity is not new, and there is a wide array of concepts designed to the capture different ways that digital technologies facilitate such innovations, including the digital party (Gerbaudo, 2018; 2019), the hybrid campaigning organization (Dennis, 2018; Karpf, 2012; Vromen, 2017), and the movement party (Kitschelt, 2006; Kavada, 2019). This article seeks to compare Momentum to these frameworks, assessing whether it is a digital pioneer or reproducing traditional, hierarchical group dynamics using new tools.

At the national level, I find that Momentum replicates some of the organizing and campaigning practices of political parties (Kreiss, 2012; Stromer-Galley, 2014). There is little evidence of the leadership using the digital feedback loops available on Facebook and Twitter to integrate member feedback within the group's decision-making. Instead, the leadership issue a high volume of requests, asking supporters to complete specific tasks. Unlike other partypolitical actors in the UK, the leadership fosters a collective identity that underpins these actions by drawing on a mixture of memes, emojis, and provocative videos. Such cultural appeals are usually created into existence by informal networks (Penney, 2017); this article shows how formal organizations are adapting these methods to support forms of controlled interactivity. While this seems to reject claims of a people-powered movement, by conducting ethnographic research with a group in Portsmouth, I observe how this vision is realized at the local level. Here, semi-public and private communication on Facebook supports semiautonomous forms of community activism. By using social media to underpin different organizational norms and campaigning tactics at different spatial levels, Momentum represents the latest example of organizational hybridity.

This article contributes to the literature on social media and political campaigning, specifically the phenomenon that Chadwick and Stromer-Galley (2016) describe as the partyas-movement mentality in which party-political organizations use digital tools to draw upon engagement repertoires associated with social movements. I argue that adopting an intraorganizational perspective reveals the significance of spatial dynamics when seeking to understand innovations in digital campaigning. Drawing on the work of Kavada (2019), I propose the concept of the "movement faction" to capture how Momentum can contest national Labour party elections in a formal, controlled way while providing its members with nonhierarchical forms of participation and organization at the local level. 


\section{Understanding Decision-Making in Hybrid Organizations}

Momentum (2016: 2-3) has two primary aims concerning member involvement. Firstly, it wants to democratize the Labour Party, providing more influence for rank-and-file members in the policy-making process, outside of voting at the annual party conference and in internal elections. Secondly, it seeks to create a network of local groups, in which grassroots activists can launch campaigns on issues they prioritize. In this article, I explore if these aims have been delivered, and the role that Facebook and Twitter play in facilitating this.

In doing so, I draw on the literature on organizational hybridity within political communication. Chadwick (2007) argues that the internet has fostered a remarkable period of organizational change, as parties that were once rigid hierarchies use digital technologies to draw on the tactics and horizontal networks associated with social movements. Inspired by the anti-globalization movement in the 1990s, traditional actors have adapted digital network repertoires pioneered by these social movements. These repertoires consist of convergent forms of online citizen action (such as petitions and fundraising), increasing opportunities for collaborative forms of engagement with citizens, and the fusion of cultural and political discourse (Chadwick, 2007: 287). This organizational hybridity has resulted in the formation of new structural forms that use digital media to provide innovative forms of mobilization.

Adopting a similar approach to Chadwick but in a new temporal context, Gerbaudo (2019: 188) recognizes how the design of popular social platforms have shaped a range of party-political organizations, such as the Five Star Movement in Italy, Podemos in Spain, and Momentum. In what Gerbaudo $(2018 ; 2019)$ describes as the digital party, social media has not only become a means of communication for political groups, but it is also intrinsically linked to their structure and tactics. These groups draw upon the norms of communication present on social media when mobilizing supporters, accounting for; (1) changes in how social relationships are formed and managed, (2) new modes of political expression, and (3) personalized forms of political identity formation (Bennett and Segerberg, 2013; Kavada, 2015; Papacharissi, 2010; Vromen, 2017). In practice, Gerbaudo (2018; 2019) illustrates how platforms like Facebook and Twitter are integral tools for building large networks of supporters. While this creates opportunities for interaction, it does not necessarily lead to increased influence, as charismatic leaders can and do still wield significant authority (Gerbaudo, 2018).

The concept of the movement party helps to explain this tension within party-political organizations. Defined by Kitschelt (2006: 28) as "coalitions of political activists who emanate 
from social movements and try to apply the organizational and strategic practices of social movements in the arena of party competition", Kavada (2019: 199) observes how movement parties attempt to balance the desire for electoral victory with a vision to radically transform internal party structures and empower grassroots decision making. This demand for involvement stems from the formative experiences of young activists in social movements, such as Occupy (Bennett and Segerberg, 2013; Kavada, 2015; 2019) and the growing popularity of social media, and its potential for collaborative engagement.

While often promised by political groups, such potential is not always delivered. Several studies have challenged the reductive assertion that the use of social media is, in itself, democratizing (Gerbaudo, 2019; Kavada, 2019; Kreiss, 2012; Penney, 2017; Stromer-Galley, 2014). Instead, the language of democracy has become a powerful way of engaging supporters while still maintaining the hierarchical structures of the past (Gerbaudo, 2019; Watts and Bale, 2019). In this sense, we need to distinguish between organizational hybrids that are genuinely committed to enhancing opportunities for involvement in decision-making and those who adopt the discourse to accrue support for predetermined goals (Kavada, 2019: 202).

Some hybrid campaigning organizations, such as 38 Degrees in the UK (Chadwick and Dennis, 2017; Dennis, 2018), GetUp! In Australia (Vromen, 2017; 2018), and MoveOn in the United States (Karpf, 2012; 2016), prioritize forms of listening on social media to give their supporters a meaningful opportunity to shape the direction of the organization (see Hall, 2019). In what Karpf (2016) describes as analytic activism, this can come in the form of explicit requests for supporters to provide quantitative (likes; shares) or qualitative (comments) feedback, or through internal processes whereby staff track analytics, such as clickthrough rates and $\mathrm{a} / \mathrm{b}$ testing, as a proxy measure of their preferences. When determining the level of support behind an issue or generating ideas for specific tactics, these feedback loops enable the leadership of these multi-issue advocacy groups to diffuse some decision-making responsibilities to grassroots supporters at strategically significant moments (Dennis, 2018).

Alternatively, organizations may seek to focus the activity of activists around leaderdefined objectives. As Stromer-Galley (2014: 177) reflects, “campaigns ultimately construct and use citizens as objects they need to manage through controlled interactivity in order to reach their objective". Typically applied to campaigning conducted by political parties, citizens participate through activities that were popularised in the post-war era, such as door-to-door canvassing and voter mobilization (Kavada, 2019). Here, social media is useful in mobilizing citizens to complete these acts but lacks any substantive connection to decision-making (Kreiss, 2012; Stromer-Galley, 2014). Even in those campaigns credited for harnessing the 
transformative impact of digital technologies, such as the Obama campaigns in the 2008 and 2012 US presidential elections, the value of citizen involvement was in amplifying key messages to wider communities online, rather than substantive influence over strategy (Stromer-Galley, 2014: 178).

Still, the perception of efficacy is central to controlled interactivity. Those designing such opportunities emphasize grassroots empowerment, but this comes through increasing personalization and the use of emotive campaign messages that an individual can relate frame around their lived experience (Bennett and Segerberg, 2013). Ultimately, this leads to parasocial interactions with the leadership, in which supporters feel like they play an instrumental role within the community by engaging with these messages on a personal level, but the campaign itself remains focused around its leader-driven goals.

Outside of parties, other affiliated organizations make use of similar techniques. In what Gibson (2012: 187) describes as citizen-initiated campaigning, activists who are not party members can use digital tools provided by the party to participate on its behalf. Dommett and Temple (2018) and Rhodes (2019) illustrate how Momentum's involvement in the 2017 UK general election fits within this tradition. Described as a satellite campaign (Dommett and Temple, 2018), Momentum organized citizens to undertake tasks typically associated with party-political campaigning, such as canvassing voters with a phone banking tool, supporting voter registration efforts on social media, and distributing activists to marginal constituencies. ${ }^{2}$ In doing so, local groups of Momentum took on some of the responsibilities that are traditionally given to branches of the formal party structure. Here, autonomy is understood in relation to the tactical control of these actions (Dommett and Temple, 2017: 197; Gibson, 2015: 187; Rhodes 2019). In this article, I look to extend this interpretation of autonomy to include involvement in decision making throughout a campaign, from setting issue priorities to deciding on tactics.

\section{Methods}

I build my argument by drawing upon a mixed-method research design, combining a qualitative analysis of posts from Facebook and Twitter with semi-structured interviews with organizers, members, and supporters of Momentum from Portsmouth and the wider South East region.

To examine how these platforms are used in different spatial contexts, I compare the national organization with a local group based in Portsmouth. The social media data was 
collected over one month, July 2018, from the web pages outlined in Table 1. All posts from public-facing Facebook pages were extracted using Netvizz, a tool that enables users to export all posts authored by the Page owner (Rieder, 2013). Data from Twitter was retrieved using rtweet (Kearney, 2018) through the standard (public) Application Programming Interface (API). I analyse political communication across Facebook and Twitter to document and observe the differences that exist in the strategy adopted across multiple platforms (Bode and Vraga, 2017). Given concerns surrounding the collection and analysis of social media data, I draw upon the framework offered by Williams, Burnap and Sloan $(2017: 1163)$ that states that organizational accounts, such as those used in this study, do not pose an ethical risk.

Table 1. Details of data collected from Facebook and Twitter

\begin{tabular}{lcc}
\hline \multicolumn{1}{c}{$\begin{array}{c}\text { Page on } \\
\text { Facebook/Twitter }\end{array}$} & URL & n of posts \\
\hline $\begin{array}{l}\text { Momentum } \\
\text { (Facebook Page) }\end{array}$ & https://www.facebook.com/PeoplesMomentum/ & 136 \\
$\begin{array}{l}\text { @PeoplesMomentum } \\
\text { (Twitter account) }\end{array}$ & https://twitter.com/PeoplesMomentum & 401 \\
$\begin{array}{l}\text { Momentum } \\
\text { Portsmouth } \\
\text { (Facebook Page) }\end{array}$ & https://www.facebook.com/MomentumPortsmouth & 7 \\
$\begin{array}{l}\text { @PortsMomentum } \\
\text { (Twitter account) }\end{array}$ & https://twitter.com/PortsMomentum & \\
\hline
\end{tabular}

All social media posts $(n=553)$ were manually read and coded to identify the service feature used, its strategic function, and the topic addressed. The coding framework (see Appendix 2) was developed inductively after pilot coding a sample of posts $(n=200)$ from June 2018. This analysis was not undertaken to produce statistical correlations, especially given the small sample size and lack of inter-coder reliability testing, but to provide a better sense and understanding of the themes present within the dataset.

This study faces some limitations. Firstly, Portsmouth Momentum represents a single case from over 170 groups. Across this network, there is significant variation in size and campaigning practices, with some focusing on issue activism and others prioritising political education (Interview 20, March 2019). Portsmouth was selected as it draws on both approaches in its activities. Although such variation means that it is difficult to locate a typical case, this 
article has value in providing a new case study to the growing literature on how local groups in Momentum operate, and the results should be interpreted within this context (see Dommett and Temple, 2018; Rhodes, 2019).

Secondly, this study focuses on posts from a single month, in which Momentum was involved in internal Labour Party elections. This sampling frame was selected due to the importance of these elections in achieving the organization's stated aims. As a result, one may expect to find more examples of controlled interactivity, given that successful campaigns often have a clear organizational hierarchy (Kreiss, 2012).

I seek to overcome these limitations by triangulating the qualitative analysis of posts with interviews with 15 members and supporters from the South East region, ${ }^{3}$ four members of the Steering Committee in Portsmouth, and one member of staff from the national organization (see Appendix 1). Interviewees were selected through snowball sampling based on contacts made following requests to the Steering Committee and by attending public meetings as a non-participant observer. Details of those members who agreed to participate have been anonymized to protect their identity. The ethnicity and gender of interviewees should not be implied from their pseudonyms. By combining an analysis of posts from social media with ethnographic interviews, this article goes beyond an interpretation of what is visible online, connecting observations of digital communication with an understanding of the motivations that drive them.

\section{Findings}

Momentum at the National-Level: Controlled Interactivity in the People-Powered Movement

At the national level, the opportunities for meaningful interaction with the leadership and the group's strategic direction were limited. Instead, members were asked to undertake specific acts. As a result, communication on Facebook and Twitter was often one-way and resolutely focused around the targets set by the leadership. This controlled interactivity is evident in three ways. Firstly, by shaping the conditions for engagement by grassroots activists. Secondly, through sharing news coverage to encourage supporters to become fee-paying members. Thirdly, by drawing on humour and provocation to foster a collective identity. Leaders present the group as outsiders on social media, doing electoral politics differently, further strengthening the narrative claims of movement-based politics. 
The most frequent posts across the national pages were to instruct members to undertake an action on the request of the leadership. As Figure 1 illustrates, this predominantly focused on calls for supporters to vote for Momentum-backed candidates in elections to the National Executive Committee (NEC), the governing body responsible for setting the overall strategic direction of the Labour Party. These requests were often made with messages designed to resonate with a supporter's sense of efficacy. This included examples of when its membership base had previously had their involvement constrained, referring to the decision by the Labour Party executive to charge $£ 25$ for registered supporters to vote in the 2016 leadership election, compared to $£ 3$ in the vote a year earlier (Momentum, 2018g). The group also appealed for possible future involvement, claiming that the \#JC9, the nine Momentumbacked candidates, were needed to democratize decision-making in the party (Momentum, 2018f).

II) Momentum

The \#LabourNEC elections open today !! Be sure to

1 Find your email ballot

2 Vote for the \#JC9

3 Let us know you've voted

yourlabournec.co.uk

4 Also vote for your NPF candidates:

bit.ly/NPF18JC

5 Chill

\section{VOTE \#JC9 FOR LABOUR NEC!}

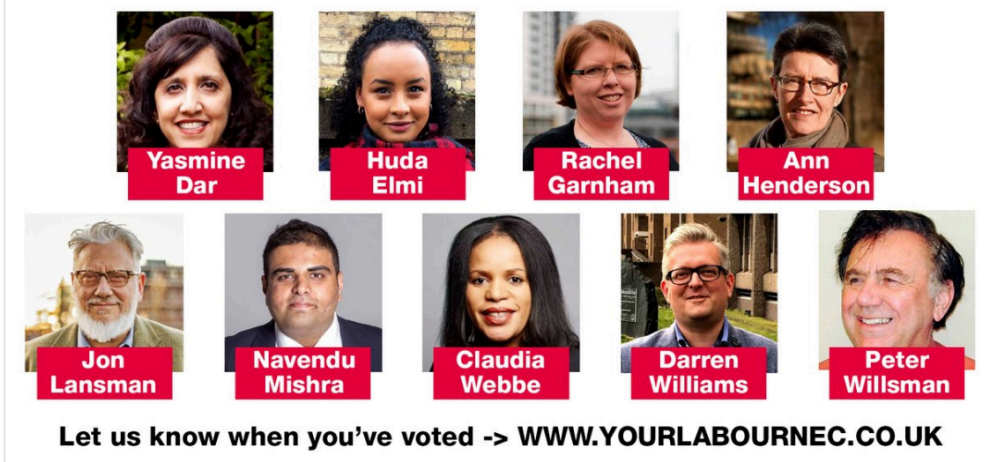

Figure 1. An example of members being instructed to vote in the NEC elections 
Member involvement in the \#JC9 campaign was limited to the national accounts sharing posts by members who had either indicated their support for the candidates or had cast their vote and were encouraging others to do the same. This was one area where local organizers noted an inherent tension between the leadership's claims of people-power and its electoral ambitions. As “Todd” (Interview 3, July 2018) reflects:

I think that the opportunity to have a faction in the Labour Party that represents the left is a great opportunity... But you have no say over the slates [for internal elections]. I think that Momentum should elect their slates. One thing that makes people feel disconnected is when there are internal Labour elections, and there is Momentumbacked candidates, and you have not necessarily had any say over who they are. Like the JC9 campaign in the current election, which has kind of felt very artificial.

This alludes to the difficulty of honouring a commitment to democratized forms of decision making in electoral politics. While Momentum claims that it wants to offer substantive forms of influence to the grassroots of the Labour Party, it cannot make such radical changes without the support of the NEC. Therefore, the group draws on controlled interactivity to shape voting preferences, with a promise of future reforms.

Outside of these requests, examples of feedback loops between the leadership and supporters were rare. While three petitions were shared during July, there was no evidence to suggest that these had been chosen on the basis of the explicitly-communicated priorities of the membership. Two petitions, one calling for the Conservative Party Chairman, Brandon Lewis MP, to resign for breaking the pairing agreement during a vote in the House of Commons ${ }^{4}$ and another requesting a bank holiday if England won the World Cup, were both linked to proposals made by the Labour Party leadership. The only interactive polls that were shared were on popular policy positions, with followers asked if the rail network should be nationalized (Momentum, 2018j). While the national pages occasionally requested feedback, such as asking supporters to share their discontent about a below-inflation public sector pay rise (Momentum, 2018e), there were no previous or subsequent posts to suggest that this feedback was being analyzed to guide future strategy. ${ }^{5}$

Secondly, the leadership frequently draws on news coverage to encourage supporters to become a full member. As Figure 2 shows, requests to join the organization came in a number of forms. Leaders amplify positive reporting of the organization's successes by way of showing the viability of its campaigning. This included a Guardian story of the group's first training event in Scotland (Momentum, 2018h) and an article on how Emma Rees and Adam Klug, two co-founders of the organization, were drawing on their experiences with Momentum 
to advise activist groups in the United States (Momentum, 2018i). Increasing the group's membership in this way has strategic benefits, providing more potential votes in Labour Party internal elections (Watts and Bale, 2019: 101) and additional finances, given that 95 per cent of its current funding comes from these fees and small donations (Cowburn, 2018).
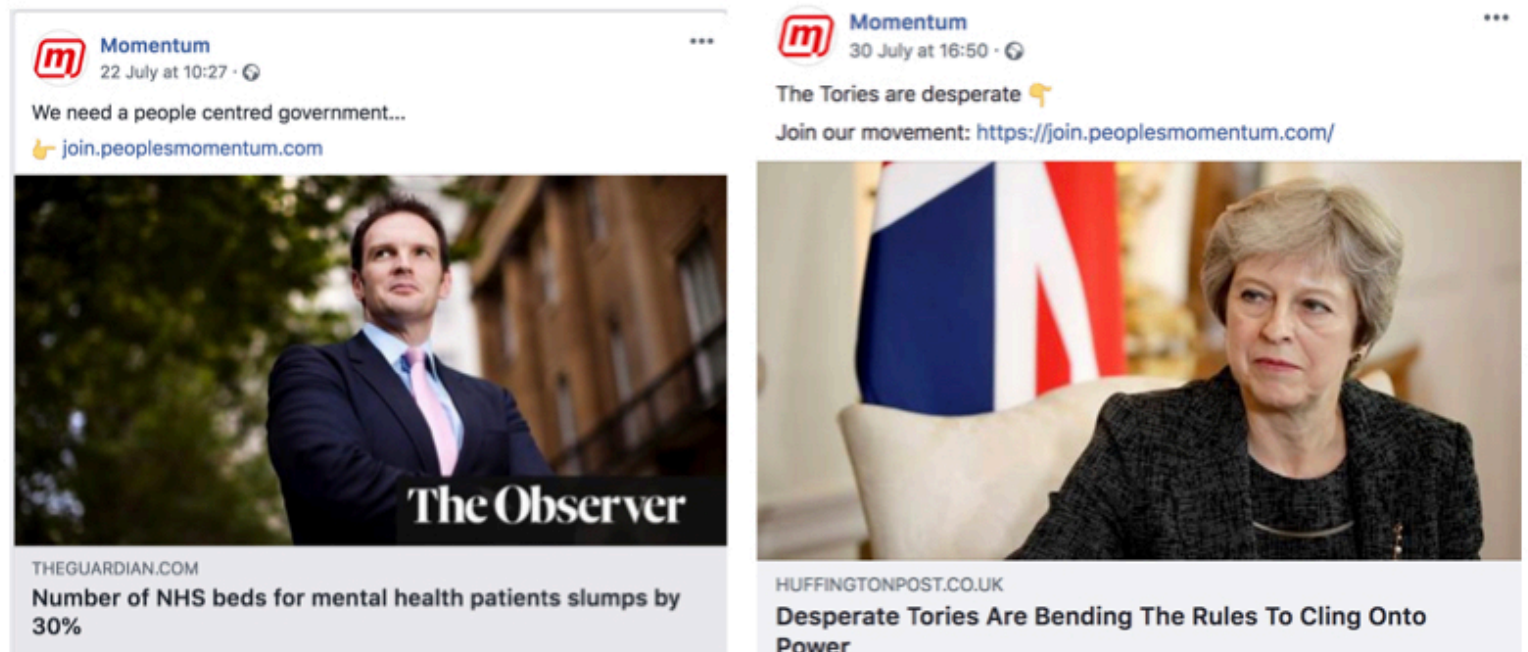

HUFFINGTONPOST.CO.UK

Desperate Tories Are Bending The Rules To Cling Onto Power
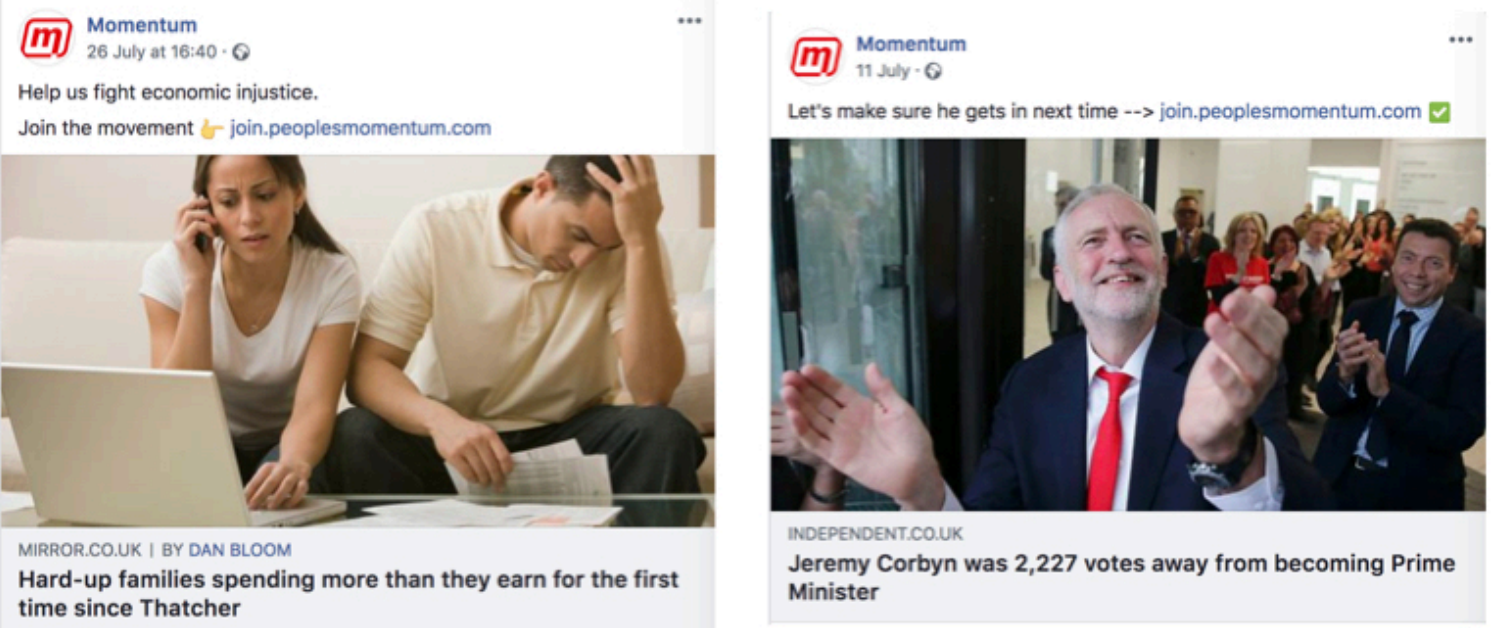

NDEPENDENT.CO.UK

Jeremy Corbyn was 2,227 votes away from becoming Prime Minister

Figure 2. Examples of news coverage used to drive membership growth

Thirdly, Facebook and Twitter are used to form a collective identity across its network of members and supporters. As Figure 2 shows, by sharing articles on issues like austerity and cuts to healthcare provision, the leadership cultivate a rationale for engagement. While posting 
professional news coverage on social media to provide this justification is not new (Chadwick and Dennis, 2017), the organization's strategic use of media criticism is noteworthy.

Rather than avoiding it, antagonistic news coverage of Momentum is embraced by the leadership and used to further claims that they are outsiders, somehow distinct from the norms of party-political organizing that have given rise to a sense of anti-politics in the UK in recent decades (Hay, 2007). As Figure 3 shows, this can be seen in the video the group produced to celebrate reaching 40,000 members (Momentum, 2018d). With a tagline "they slate us, we grow", the video mixes criticism of the group from commentators, journalists, and politicians with music from Chopin. As expected, this predominantly focuses on the Conservative Party and right-wing commentators. Quotes are included from Michael Portillo, former Cabinet Minister of the Conservative Party, who claimed that Momentum had "infiltrated and taken over the Labour Party", and the journalist Toby Young, who described them as "a small, NeoMarxist cult" on the BBC's Sunday Politics. However, the video also features prominent figures within the Labour Party. Tristram Hunt, the then Labour MP, labelled Momentum as a "shady group" on Channel 4 News, while Chuka Umuna MP claimed that the organization should be "wound up and shut down" during a meeting of the Home Affairs Select Committee.

This condemnation of Momentum is contrasted with a message to members at the end of the video; "Thank you to everyone who helped us get this far". As "Harry" (Interview 1, July 2018), a member of the Steering Committee in Portsmouth, illustrates, this kind of subversive engagement with media criticism helps to foster an identity amongst the group and deepen the connections between supporters:

I talked to my partner about the video that they made with all the people slating Momentum with the piano theme tune over it. I found that absolutely hilarious. This is amazing, I love this! That is how I feel about criticism myself. We're here. More people are joining. Just keep on saying that about us.

This communicative style is provocative and confrontational, and it helps to create the perception of Momentum as an outsider within the context of Westminster politics. More significantly, it shows the group's opposition of other ideological perspectives and factions within the Labour Party. This approach is described by Watts and Bale (2019) as intra-party populism, whereby Momentum uses the language and imagery associated with movement politics to position the organization as representative of ordinary people who are mobilizing against political elites. In the context of the NEC elections, the focus was those associated with New Labour, and how Momentum-backed candidates were essential in delivering a more 
democratic, grassroots-led Labour Party. Ultimately, this helps to shape the group's identity by defining what they oppose.

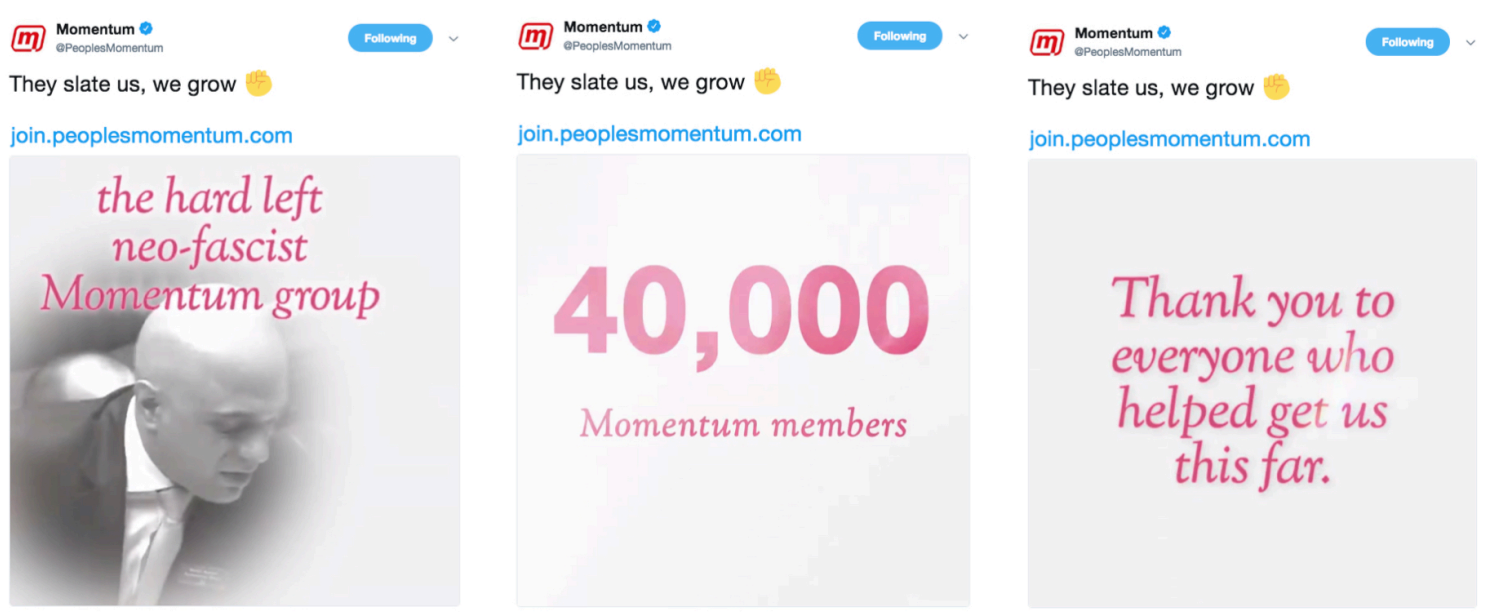

Figure 3. An example of Momentum using media criticism to foster a collective identity

While many of the group's videos are compilations of existing footage, Momentum also produces its own short features. Some raise awareness of social and political issues, such as the UK's role in the arms trade (Momentum, 2018c). Others are used in tandem with the group's requests for members to complete specific tasks. The sampling frame fell during the 2018 football World Cup, where the England team unexpectedly reached the semi-finals of the competition. As shown in Figure 4 (Momentum, 2018b), Momentum compared the hardships that supporters of Jeremy Corbyn had faced, to the struggles of the England team in recent international tournaments. The clip ends with a request for members to vote for Momentum backed candidates in the NEC elections; the "team that will beat the odds". The images of the nine candidates are shown with commentary from the national team's victories over Panama, Colombia, and Sweden. 


\section{yourlabournec.co.uk}

\#JC9 \#LabourNEC \#ENGCRO

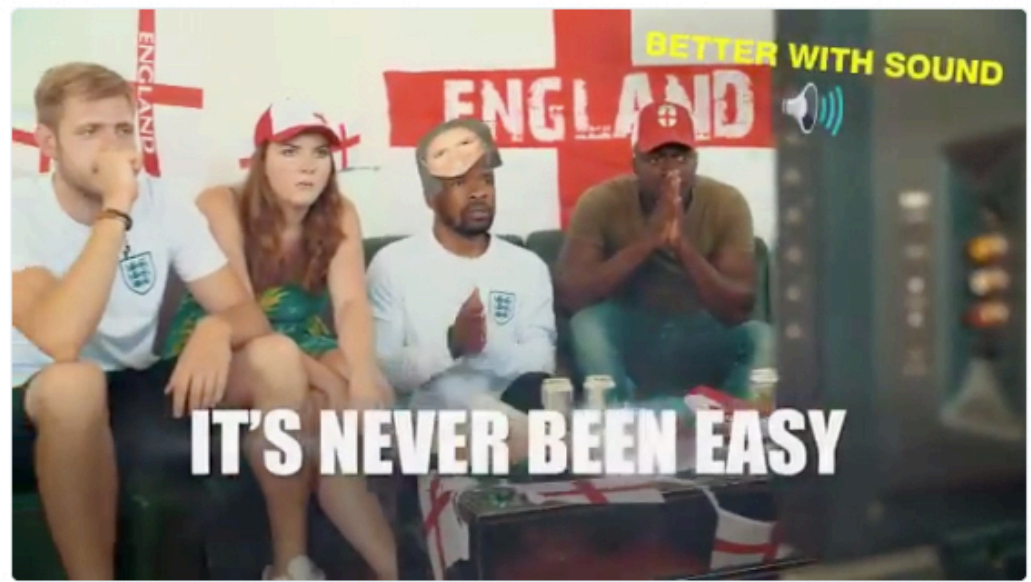

Figure 4. A video designed to support requests for member participation

What links these videos is the style of communication. The leadership draws on a youthful, digitally-enabled civic vernacular that exists online. Whereas party political campaigning online often replicates professional norms refined across other media (Lilleker et al. 2017), Momentum embraces the humour and irony that typifies the social web. Interviewees identified this communicative style as a distinguishing feature of the group's social media presence, something distinctive that members can mobilize around (e.g. Interview 1; Interview 2; Interview 5, July 2018). "Tiago" (Interview 16, February 2019), a supporter from London, recognizes the value of these videos in achieving this:

They use Facebook to spread their message. They post videos that they want people to share. I think that is the main aim on Facebook. Likes and Comments tend to get lost in the News Feed. They create videos that people want to share.

Posts are deemed to be "off-the-cuff" (Interview 4, July 2018) and "a bit of fun" (Interview 19, February 2019). Therefore, the playful, communicative style adopted helps citizens overcome the cognitive load associated with political self-expression on social media. This helps to widen engagement, with "John" (Interview 18, February 2019) noting that it was a video that triggered their involvement with the organization. 
This communicative style develops the narrative claim of "people power" and that Momentum is bringing social movement organizing to the arena of party politics. Drawing on Enli's (2015) conceptualization of mediated authenticity, Momentum draws on the genre conventions of Facebook and Twitter as if to appear relatable. The posts that I analyzed were raw. They were emotional and impromptu. Ultimately, they replicate many of the norms of communication that users experience day-to-day. In doing so, they represent something dramatically different from the stage-managed communication that characterizes other actors working in the same space. While I found little evidence of the grassroots influencing decision making using social platforms, the way in which the organization presents itself is crucial in understanding why members perceive Momentum to be a movement (Interview 2; Interview 3, July 2018; Interview 6; Interview 7; Interview 13, November 2018).

\section{Momentum at the Local-Level: Evidence of Grassroots Organizing}

At the local level, the most notable difference was how the Portsmouth group seemed relatively inactive on Facebook and Twitter. Despite the lack of public-facing communication, there were some similarities with the national account. Firstly, there were calls for local supporters to complete specific acts. While this included the aforementioned \#JC9 campaign for the NEC elections (Momentum Portsmouth, 2018c), members were also encouraged to support Momentum-backed candidates within their local Constituency Labour Party (CLP) (Momentum Portsmouth, 2018a). Secondly, the Portsmouth group amplified requests from the national accounts to join the organization (Momentum Portsmouth, 2018b). However, there were also areas of divergence. The provocative and youth-orientated style present on the national pages was notably absent. As "Catherine" (Interview 5, July 2018) reflects, this is a result of a lack of expertise required to do this confidently, as they did not feel that they had a clear grasp of the tone, format, and style developed at the national level. Furthermore, there was some evidence of direct feedback loops, as local organizers published a request for members to join them for a meeting of the Steering Committee (Momentum Portsmouth, 2018d) - a request that illustrates a significant intra-organizational distinction.

By drawing on interviews with local organizers, members, and supporters, it became clear that a private Facebook group provides a valuable tool in supporting autonomous forms of organizing. As “Annabelle" (Interview 2, July 2018) reflects, this speaks to the group's broader goal of democratization: 
Momentum is also about being active in the community and changing things at the local level. I think that is what Momentum is trying to do, incorporate that into what it means to be part of the Labour Party, rather than just winning elections.

The private group is key in facilitating this. ${ }^{6}$ While the public-facing Facebook Page is occasionally used for requesting member feedback, posts are predominantly aimed at wider audiences, with a view of encouraging them to get involved. As Catherine (Interview 5, July 2018) observes:

I think the page is for people who are not members. The group is a closed group, so we use that for organizing, whereas the page is for the wider public. One is for organizing and one is for communicating messages... The group is really useful. Everything happens on Facebook.

The communication in the group fulfils numerous functions. It includes the organizational work for campaigns led by the national office. This was evident through their involvement in the "UnSeat" campaign, a nationwide mobilization that targets constituencies where Conservative Party politicians have a small majority and are susceptible to a Labour Party victory. While the event drew on several digital tools, such as Eventbrite to manage the details of attendees and a Facebook event for promotion to wider audiences, those involved used the Facebook group to share logistical responsibilities. This illustrates its strategic benefits for organizing on-the-ground actions. As Harry (Interview 1, July 2018) reflects, the end-result was surprising for the organizers:

It was an amazing event... We used the group to help organize a canvassing event beforehand, where we had 50 or 60 people out. The previous biggest canvassing efforts in Portsmouth that I had seen had probably 15 or $20 \ldots$ For loads of people, it was there first time... We went out canvassing as a group in the Fratton Ward and got around 150 Labour pledges. In the end, Tom Coles, who stood in Fratton, only won by about 70 votes.

While Catherine (Interview 5, July 2018) recognizes that this is something that Momentum could arrange from the central office, the benefit of this being member-led is that those involved understand the nuance of the local political context.

Outside of nationally led initiatives, the Facebook group acts as space for members to establish their own campaigns. As “Ashley" (Interview 11, November 2018) observes, this can lead to ad-hoc events on issues that local supporters prioritize, such as a vigil organized in June 2018 to commemorate the first anniversary of the 72 people killed in the Grenfell Tower fire. 
Ashley noted how this emerged from a conversation with other members in the group, rather than any direction from the Steering Committee or formal approval from the wider membership.

Members also use the group to organize political actions that have no public affiliation with Momentum. A campaign that came up in a number of interviews (Interview 8; Interview 10; Interview 11; November 2018) was the "Pompey Against Universal Credit" group. Although formed by a member of Portsmouth Momentum, the group has no visible connection to Momentum and is instead affiliated with the trade union, Unite (Pompey Against Universal Credit, n.d.). Despite this, members took an active role in this campaign, using the Facebook Group and the monthly, face-to-face meetings to discuss strategy and organize demonstrations. As "Aaron" (Interview 13, November 2018) observes, the Facebook Group becomes a space in which members can mobilize around the issue interests of individual members; "it's for organizing ourselves, for protests and meetings. Not even Momentum ones, but things that are related". As a result, the local group is not tied to the organizational identity established at the national level, but instead draws on a more flexible identity that is inclusive of their priorities and those established by other political groups in the community.

Outside of the organizational capacity of the group, members value the discursive opportunities that it provides and the way it complements the decision-making process more broadly. It provides a space to discuss local issues and, if necessary, formulate a collective response. This includes policy decisions made by the local council, such as a campaign for increased levels of social housing, or issues that arise within the local branch of the Labour Party, including candidate selection processes. Furthermore, the Facebook group acts as a space for members to form connections with others, with several interviewees reflecting on their positive experiences of everyday political talk (Interview 6; Interview 7; November 2018). According to Todd (Interview 3, July 2018), by sharing and reflecting on issues and events in the community that members relate to, this helps to create a "closely-knit" group.

While the Portsmouth Momentum has an elected Steering Committee, its function is predominantly facilitative, taking on the bulk of the organizational responsibilities and providing a structure for the debate and decision-making practices that direct the priorities of the group. As Annabelle (Interview 2, July 2018) reflects, supporters are integral to delivering their vision of consensus-driven decision making: 
It is very much a democratic, horizontal organization, and in my role, I try to build relationships and build links with members. We have regular Steering Committee meetings, but we also open it up to anyone that is a member. Anyone can attend and have their say, and then we try and find a consensus to move forward.

This process is welcomed by the local activists, with "Penny" (Interview 9, November 2018) describing how the Chair of the group "gives people a fair chance to speak, and they normally encourage people to speak and express their views", claiming it is "a lot fairer" than the meetings of their CLP.

This behind the scenes perspective shows how different features on Facebook can be used to diffuse decision-making power away from the leadership. For Annabelle (Interview 2, July 2018), this resonates with their formative political experiences in the Stop the War Coalition and the student protests of 2010:

On the local level, it feels like a social movement. We are left to our own devices to an extent. We get some support from the head office when we need it, but we are very rarely dictated to, or told to do this or that, outside of very obvious things. We have a local group that meets regularly and organizes democratically. We decide what our priorities are.

This paints a very different picture to the moments of controlled interactivity that characterized the relationship between the leadership and the wider membership at the national level. While other local branches may operate with more clearly defined hierarchies, the comparison between the national organization and Portsmouth Momentum illustrates a distinctive intraorganizational dynamic.

\section{Discussion and Conclusion: The Movement Faction}

By analysing the Facebook page and Twitter profiles of the national organization and an associated local group, I found little evidence of Momentum fulfilling its "people-powered" vision. Instead, members and supporters are frequently instructed to undertake tasks at the direction of the leadership. These requests often have an electoral goal in mind, with the national group seeking to ensure that Momentum-backed candidates are elected to key positions within the Labour Party or are designed to grow its network of members. These objectives are mutually reinforcing, as encouraging lurking supporters to become members increases their vote share within internal Labour Party elections. However, this is not a straightforward case of controlled interactivity. Through interviews with local organizers, 
members, and supporters in Portsmouth, I found evidence of semi-autonomous community activism organized through a Facebook Group. Although Bennett and Segerberg (2013) illustrate that social media platforms can be used to support different forms of political organization, either rigidly managing political action (see organizationally brokered networks) or fostering unstructured, member-led campaigns (see crowd-enabled networks), Momentum is significant in that it draws on aspects of both collective and connective action within its organizational form.

Momentum uses social media to move between Karpf's (2012: 19) models of digital organizing. As Table 2 shows, on the national level, a hub and spokes model is in use, whereby the central office orchestrates the participation of the mass membership. Here, Momentum uses social media to underpin tried-and-tested tactics for winning elections. While this may seem at odds with the notion of a people-powered movement, controlled interactivity is proven to be effective in supporting electoral campaigning (Gibson, 2015; Kreiss 2012; Stromer-Galley, 2014). This is in stark contrast to the local efforts in Portsmouth, where supporters use a Facebook Group to guide collective decision-making. This represents a neo-federated model, in which relatively independent affiliate groups campaign and mobilize across the country. 
Table 2. Intra-organizational comparison of political communication strategies on social media in Momentum

\begin{tabular}{|c|c|c|}
\hline & National-level organization & $\begin{array}{c}\text { Local-Level organization: } \\
\text { Portsmouth } \\
\end{array}$ \\
\hline $\begin{array}{c}\text { Forms of } \\
\text { participation on } \\
\text { social media }\end{array}$ & $\begin{array}{l}\text { Members and supporters are } \\
\text { instructed to complete specific } \\
\text { acts at the request of the } \\
\text { leadership (see Controlled } \\
\text { interactivity, Stromer-Galley, } \\
\text { 2014; Satellite campaigns, } \\
\text { Dommett and Temple, 2018; } \\
\text { Rhodes, 2019) }\end{array}$ & $\begin{array}{l}\text { Participation within a private } \\
\text { Facebook group } \\
\text { Used to discuss issues, set } \\
\text { strategic goals, and plan protest } \\
\text { activity } \\
\text { Communication is directly linked } \\
\text { to decisions taken at local } \\
\text { meetings }\end{array}$ \\
\hline $\begin{array}{l}\text { Style of } \\
\text { communication } \\
\text { on social media }\end{array}$ & $\begin{array}{l}\text { Provocative and humorous } \\
\text { communication that draws on the } \\
\text { vernacular of social media (see } \\
\text { Mediated authenticity, Enli, 2015) }\end{array}$ & $\begin{array}{l}\text { Public-facing communication on } \\
\text { Facebook and Twitter is rare and } \\
\text { focused on amplifying organized } \\
\text { protest activity }\end{array}$ \\
\hline \multirow[t]{2}{*}{$\begin{array}{l}\text { Construction of } \\
\text { collective } \\
\text { identity }\end{array}$} & $\begin{array}{l}\text { Leader-led attempts to foster a } \\
\text { collective identity on social media } \\
\text { through practices of } \\
\text { communication (see Kavada, } \\
2015 \text { ) }\end{array}$ & $\begin{array}{l}\text { Collective identity formulation } \\
\text { through regular digital and face- } \\
\text { to-face discussions in small } \\
\text { groups }\end{array}$ \\
\hline & $\begin{array}{l}\text { Creating a sense of Momentum as } \\
\text { outsiders, different from other } \\
\text { factions within the Labour Party } \\
\text { and other party-political } \\
\text { organizations (see Intra-party } \\
\text { populism, Watts and Bale, 2019) }\end{array}$ & \\
\hline $\begin{array}{c}\text { Influence over } \\
\text { strategic } \\
\text { decision-making }\end{array}$ & Leader-driven & Member-led \\
\hline
\end{tabular}

This capacity for organizational and communicative experimentation is significant when one seeks to categorize Momentum as a political group. While Kitschelt (2006: 26) notes that a movement party does not necessarily have to be a formal organization seeking office through elections and can be groups of activists that draw on the "strategic practices of social movements in the arena of party competition", such opportunities are not afforded to political parties that have to manage a large membership with competing ideals. I, therefore, suggest that Momentum represents a movement faction. Much of the innovative campaigning tactics 
that Momentum use in this study and others (Dommett and Temple, 2018; Rhodes, 2019) are, in part, enabled by operating outside of the restrictions of formal party politics. Momentum does not have to represent a broad base of perspectives or adhere to strict bureaucratic forms. Instead, it can champion a distinct ideological perspective through flexible modes of organizing that are underpinned by the affordances of social media platforms.

The movement faction model brings distinctive benefits. Momentum can undertake both internally and externally-facing political action. Like other factions within the Labour Party, Momentum can compete for influence by putting up candidates for election, but it also uses social media to organize creative forms of activism on issues outside of the party manifesto. As Anna (Interview 20, March 2019), a Lead Organizer for the national organization, reflects:

Historically, factions have usually been entirely, internally focused. Win the argument inside the party in order to influence the party's direction. But what we have been able to do through Facebook is, at the same time as that, also reach out on a wider range of issues... Social media is a gamechanger from our perspective.

This further enhances the leadership's attempts to position the organization as outsiders (see Watts and Bale, 2019), as they are simultaneously distinct from the norms and practices of Westminster politics but also dissimilar to competing factions. McDowell-Naylor (2019) argues that this sense of deterritorialization is key, as Momentum can avoid the baggage of party bureaucracy while advocating party-centric forms of grassroots campaigning.

The leadership use social media to foster this sense of movement identity amongst its supporter base. Momentum does this by drawing upon a youthful, digital-enabled civic vernacular that exists online. Within the context of party politics in the UK, where messages are crafted to appeal to the opinion electorate rather than an ideological base (Panebianco, 1988), such polemic, adversarial communication offers something novel. Members spoke of how the messaging at the national level felt different. As "Elizabeth" (Interview 12, November 2018) notes:

It helps people relate to their aims more. When it's just a boring post with loads information, people just tend not to read it or watch it. But when they use things people can relate to, like when they use loads of emojis and memes, that is what people use on a daily basis when chatting to friends. 
Drawing on Enli's (2015: 131) conceptualization of mediated authenticity, this article shows how Momentum share content that lives up to the conventions of the medium, appearing to be impromptu and relatable to its supporters.

The work of the central staff on Facebook and Twitter in developing this collective identity should not be overlooked (see Kavada, 2015). They develop this distinctive voice by sharing adversarial messages that define Momentum by what they oppose. This "us versus them" dynamic operates at multiple levels, as Momentum stands in opposition to its ideological adversaries, typically the governing Conservative Party, but also other factions within the Labour Party. The videos shared are instrumental to this strategy, continuing a trend of social movement actors using visual forms of communication to promote a shared vision and direction for the group (Vromen, 2018).

This approach has similarities with the campaign to elect Senator Bernie Sanders as US president in 2016 (Penney, 2017). This is perhaps unsurprising, given that the organizers working on this campaign were brought in to advise Momentum on digital strategy (Rhodes, 2019). However, in this case, the provocative, cultural appeals were created by unofficial networks of activists. This article illustrates how organizations are seeking to adapt and draw upon this style of communication in a controlled way.

At the local-level, I argue that Momentum represents much more than an "ad hoc electoral vehicle" (Watts and Bale, 2019: 101). The interviews illustrate how a Facebook Group provides a valuable tool for activism around both nationally-coordinated issues and member-led campaigns. This activism sees Momentum work with other organizations in the local area, overlooking conventional organizational structures. Here, the Facebook Group fulfils a number of functions, allowing members to discuss and learn about political issues, set strategic goals, and plan protest activity. While this is not without reputational risk for the national leadership (see Penney, 2017), this movement-style campaigning meets the expectations of tangible influence that supporters desire. In doing so, Momentum draws on the organizational practices and modes of engagement associated with social movements within a party-political context (Kavada, 2019; Kitschelt, 2006). It is an example of what Chadwick and Stromer-Galley (2016) describe as party-as-movement mentality, in which party norms are being renewed from the outside by digitally-enabled activist networks.

Such transformation inevitably brings challenges. This was most evident in the interviews with members and supporters, who shared a sense of frustration over the controlled interactivity at the national level in relation to the NEC elections. As Kavada (2019: 199) notes, such difficulties are to be expected, as movement parties "are constituted around contradictory 
objectives - to win the electoral game and to transform the system of representative democracy." In order to achieve its goals, Momentum has to succeed within the very system it seeks to change. Momentum requires representation on key decision-making bodies, namely the NEC, in order to reform the internal structure of the Labour Party and shape the manifesto around its preferred policy agenda. Even if a Momentum-backed candidate won a general election, a government requires the support of backbench MPs to pass legislation. Since becoming Leader of the Opposition in 2015, Jeremy Corbyn has struggled to command the support of his fellow MPs in the Parliamentary Labour Party, perhaps best illustrated by the motion of no confidence passed in 2016. This means that Momentum also has to engage with the existing branch system of the Labour Party, supporting prospective candidates at the constituency level. As a result, in order to achieve its core aims, Momentum has to play by the rulebook of traditional party politics while advocating a radical participationist agenda that is responsive to the changing demands of its supporters.

This study offers a snapshot of Momentum during its launch phase (see Gerbaudo, 2019: 194), as it draws on modes of controlled interactivity to grow the number of fee-paying members and attain influence within the party. A key question for future research is what success in the internal Labour Party elections, and a potential general election victory, would mean for the evolution of Momentum. The candidates backed by the group in 2018 NEC elections won all nine available places. If Momentum becomes the dominant force on the decision-making bodies of the Labour Party, can it deliver opportunities for influence for its network of supporters? If the Labour Party, led by Jeremy Corbyn, wins a general election, can it draw on the enthusiasm of Momentum activists while in government? Retaining the appeal of a movement while succeeding in formal elections represents a significant challenge (Dommett and Temple, 2018; Kavada, 2019; McDowell-Naylor, 2019). As Mosca and Quaranta (2017) illustrate in their study of movement parties across Europe, electoral victory often results in parties moving away from the movement tradition, as the issues that initially capture the enthusiasm of activists do not easily translate into formal policymaking. Furthermore, beyond Momentum and the Labour Party, the concept of the movement faction could also be used to analyse the extent to which digital technologies provide a legitimate voice for grassroots supporters in the decision-making processes of other political parties in the UK. 


\section{Bibliography}

Bennett, W. L., \& Segerberg, A. (2013). The Logic of Connective Action: Digital Media and the Personalization of Contentious Politics. Cambridge: Cambridge University Press.

Bode, L., \& Vraga, E. K. (2017). Studying Politics Across Media. Political Communication. $35(1), 1-7$.

Chadwick, A. (2007). Digital Network Repertoires and Organizational Hybridity. Political Communication, 24(3), 283-301.

Chadwick, A., \& Dennis, J. (2017). Social Media, Professional Media, and Mobilization in Contemporary Britain: Explaining the Strengths and Weaknesses of the Citizens' Movement, 38 Degrees, Political Studies. 65(1), 42-60.

Chadwick, A., \& Stromer-Galley, J. (2016). Digital Media, Power, and Democracy in Parties and Election Campaigns: Party Decline or Party Renewal? The International Journal of Press/Politics. 21(3), 283-293.

Cowburn, A. (2017, 07/06/2017). Momentum: What Happens to the Jeremy Corbyn-Backing Organisation After the General Election. The Independent. Retrieved 26/07/2018, from https://www.independent.co.uk/news/uk/politics/momentum-what-happensjeremy-corbyn-post-general-election-2017-labour-defeat-hard-left-winga7777506.html.

Dennis, J. (2018). Beyond Slacktivism: Political Participation on Social Media. Basingstoke: Palgrave Macmillan.

Dommett, K., \& Temple, L. (2018). Digital Campaigning: The Rise of Facebook and Satellite Campaigns. Parliamentary Affairs. 71(suppl_1), 189-202.

Enli, G. (2015). Mediated Authenticity: How the Media Constructs Reality. New York, Peter Lang.

Gerbaudo, P. (2018). The Digital Party: Political Organisation and Online Democracy. London: Pluto Press.

Gerbaudo, P. (2019). The Platform Party: The Transformation of Political Organisation in the Era of Big Data. In Chandler, D. and Fuchs, C. (Eds.), Digital Objects, Digital Subjects: Interdisciplinary Perspectives on Capitalism, Labour and Politics in the Age of Big Data (pp. 187-198). London: University of Westminster Press.

Gibson, R. K. (2015). Party Change, Social Media and the Rise of "Citizen-Initiated" Campaigning. Party Politics. 21(2), 183-197.

Hall, N. (2019). When Do Refugees Matter? The Importance of Issue Salience for Digital Advocacy Organizations. Interest Groups \& Advocacy. 8(3), 333-355.

Hay, C. (2007). Why We Hate Politics. Cambridge: Polity.

Karpf, D. (2012). The MoveOn Effect: The Unexpected Transformation of American Political Advocacy. Oxford: Oxford University Press.

Karpf, D., Kreiss, D., Nielsen, R. K., \& Powers, M. (2015). The Role of Qualitative Methods in Political Communication Research: Past, Present, and Future. International Journal of Communication. 9(2015), 1888-1906.

Karpf, D. (2016). Analytic Activism: Digital Listening and the New Political Strategy. Oxford: Oxford University Press.

Kavada, A. (2015). Creating the Collective: Social Media, the Occupy Movement and its Constitution as a Collective Actor. Information, Communication \& Society. 18(8), 872-886. 
Kavada, A. (2019). The Movement Party - Winning Elections and Transforming Democracy in a Digital Era: Reflections on Paolo Gerbaudo's Chapter. In Chandler, D. and Fuchs, C. (eds.), Digital Objects, Digital Subjects: Interdisciplinary Perspectives on Capitalism, Labour and Politics in the Age of Big Data (pp. 199-204). London: University of Westminster Press.

Kearney, M. W. (2018). rtweet: Collecting Twitter Data. R package version 0.6.7. Retrieved 01/07/2018, from https://cran.r-project.org/package=rtweet.

Kitschelt, H. P. (2006). Movement Parties. In Katz, R. S. and Crotty, W. (Eds.), Handbook of Party Politics (pp. 278-290). London: Sage.

Kreiss, D. (2012). Taking Our Country Back: The Crafting of Networked Politics from Howard Dean to Barack Obama. Oxford: Oxford University Press.

Lilleker, D. G., Koc-Michalska, K., Negrine, R., Gibson, R., Vedel, T., \& Strudel, S. (2017). Social Media Campaigning in Europe: Mapping the Terrain. Journal of Information Technology \& Politics. 14(4), 293-298.

McDowell-Naylor, D. (2019). \#GE2017: Digital Media and the Campaigns. In Wring, D. Mortimore, D. and Atkinson, S. (eds.), Political Communication in Britain: Campaigning, Media and Polling in the 2017 General Election (pp. 187-208). Basingstoke: Palgrave Macmillan.

Momentum. (2016, 06/02/2016). National Committee Agenda. Retrieved 09/02/2016, from http://i.telegraph.co.uk/multimedia/archive/03570/National_Committee_3570014a.pd f.

Momentum. (2018a). About Momentum. Retrieved 23/08/2018, from https://peoplesmomentum.com/about/.

Momentum [PeoplesMomentum]. (2018b, 11/07/2018). Tweet. Retrieved May 29, 2019, from https://twitter.com/PeoplesMomentum/status/1017036548573974530.

Momentum [PeoplesMomentum]. (2018c, 19/07/2018). Tweet. Retrieved May 29, 2019, from https://twitter.com/peoplesmomentum/status/1019876663667118080.

Momentum [PeoplesMomentum]. (2018d, 23/07/2018). Tweet. Retrieved 29/05/2019, from https://twitter.com/PeoplesMomentum/status/1021423694156058625.

Momentum (2018e, 25/07/2018). Facebook Update. Retrieved 29/05/2019, from https://www.facebook.com/155710354774360/posts/683166225362101/.

Momentum. (2018f, 26/07/2018). Facebook Update. Retrieved 29/05/2019, from https://www.facebook.com/155710354774360/posts/683986945280029/.

Momentum. (2018g, 27/07/2018). Facebook Update. Retrieved 29/05/2019, from https://www.facebook.com/155710354774360/posts/685382411807149/.

Momentum (2018h, 29/07/2018). Facebook Update. Retrieved 29/05/2019, from https://www.facebook.com/155710354774360/posts/687586174920106/.

Momentum (2018i, 29/07/2018). Facebook Update. Retrieved 29/05/2019, from https://www.facebook.com/155710354774360/posts/686846861660704/.

Momentum [PeoplesMomentum]. (2018j, 30/07/2018). Tweet. Retrieved 29/05/2019, from https://twitter.com/PeoplesMomentum/status/1023872549963407360.

Momentum Portsmouth. (2018a, 01/07/2018). Facebook Update. Retrieved 29/05/2019, from https://www.facebook.com/1576918375953256/posts/1983998691911887/.

Momentum Portsmouth. (2018b, 09/07/2018). Facebook Update. Retrieved 29/05/2019, from https://www.facebook.com/1576918375953256/posts/1992036457774777/.

Momentum Portsmouth. (2018c, 27/07/2018). Facebook Update. Retrieved 29/05/2019, from https://www.facebook.com/1576918375953256/posts/2010398795938543/.

Momentum Portsmouth. (2018d, 28/07/2018). Facebook Update. Retrieved 29/05/2019, from https://www.facebook.com/1576918375953256/posts/2011348275843595/. 
Mosca, L. and Quaranta, M. (2017). Voting for Movement Parties in Southern Europe: The Role of Protest and Digital Information. South European Society and Politics. 22(4), 427-446.

Panebianco, A. (1988). Political Parties: Organisation and Power. Cambridge: Cambridge University Press.

Papacharissi, Z. (2010). A Private Sphere: Democracy in a Digital Age. Cambridge: Polity. Penney, J. (2017). Social Media and Citizen Participation in "Official" and "Unofficial" Electoral Promotion: A Structural Analysis of the 2016 Bernie Sanders Digital Campaign. Journal of Communication. 67(3), 402-423.

Pompey Against Universal Credit. (n.d.). Facebook Page. Retrieved 29/05/2019, from https://www.facebook.com/PompeyAgainstUC/.

Rees, E. (2017, 12/06/2017). What Made the Difference for Labour? Ordinary People Knocking on Doors. The Guardian. Retrieved 23/09/2019, from https://www.theguardian.com/commentisfree/2017/jun/12/labour-knocking-on-doorsjeremy-corbyn-momentum.

Rieder, B. (2013). Studying Facebook via Data Extraction: The Netvizz Application. In Proceedings of the 5th Annual ACM Web Science Conference (pp. 346-355). New York, NY, USA.

Rhodes, A. (2019). Movement-led Electoral Campaigning: Momentum in the 2017 General Election. In Wring, D. Mortimore, D. and Atkinson, S. (eds.), Political Communication in Britain: Campaigning, Media and Polling in the 2017 General Election (pp. 171-186). Basingstoke: Palgrave Macmillan.

Sparrow, A., Phipps, C., \& Quinn, B. (2016, 04/06/2016). Boris Johnson backs Andrea Leadsom for Tory leadership - as it happened. The Guardian. Retrieved 27/07/2018, from https://www.theguardian.com/politics/live/2016/jul/04/brexit-live-plan-leavevote-hysteria-boris-johnson.

Stromer-Galley, J. (2014). Presidential Campaigning in the Internet Age. Oxford: Oxford University Press.

Vromen, A. (2017). Digital Citizenship and Political Engagement: The Challenge from Online Campaigning and Advocacy Organisations. Basingstoke: Palgrave Macmillan.

Vromen, A. (2018). GetUp! in Election 2016. In Gauja, A. Chen, P. Curtin, J. and Pietsch, J. (Eds.), Double Disillusion: The 2016 Australian Federal Election (pp. 397-419). Canberra, Australia: ANU Press.

Watts, J., and Bale, T. (2019). Populism as an Intra-Party Phenomenon: The British Labour Party Under Jeremy Corbyn. The British Journal of Politics and International Relations. 21(1), 99-115.

Williams, M. L., Burnap, P., \& Sloan, L. (2017). Towards an Ethical Framework for Publising Twitter Data in Social Research: Taking into Account Users; Views, Online Context and Algorithmic Estimation. Sociology. 51(6), 1149-1168. 


\section{Appendix (1): Interviews}

Anonymity was offered to protect the identity of participants. The gender of interviewees should not be implied from their pseudonyms. Asterisk indicates participants who are not involved with the Portsmouth group.

\begin{tabular}{|c|c|c|c|}
\hline No. & Pseudonym & Role & Date \\
\hline 1 & Harry & Steering Committee for local group & July, 2018 \\
\hline 2 & Annabelle & Steering Committee for local group & July, 2018 \\
\hline 3 & Todd & Steering Committee for local group & July, 2018 \\
\hline 4 & Tony & Supporter & July, 2018 \\
\hline 5 & Catherine & Steering Committee for local group & July, 2018 \\
\hline 6 & Niki & Supporter & November, 2018 \\
\hline 7 & Tamara & Supporter & November, 2018 \\
\hline 8 & Janet & Member & November, 2018 \\
\hline 9 & Penny & Supporter & November, 2018 \\
\hline 10 & Abby & Member & November, 2018 \\
\hline 11 & Ashley & Member & November, 2018 \\
\hline 12 & Elizabeth & Member & November, 2018 \\
\hline 13 & Aaron & Member & November, 2018 \\
\hline 14 & Naomi & Supporter* & January, 2019 \\
\hline 15 & Rob & Supporter* & January, 2019 \\
\hline 16 & Tiago & Supporter* & February, 2019 \\
\hline 17 & Alice & Member* & February, 2019 \\
\hline 18 & John & Supporter* & February, 2019 \\
\hline 19 & Liam & Supporter* & February, 2019 \\
\hline 20 & Anna & $\begin{array}{l}\text { Lead Organiser - National } \\
\text { Momentum Group }\end{array}$ & March, 2019 \\
\hline
\end{tabular}




\section{Appendix (2): Descriptive Coding Framework}

Facebook

(A) Type of Facebook post

1. Native post

2. Share

3. Commented share

4. Unclear

(B) If share - type of actor

1. Member of the public

2. News media corporate account

3. News media personal/journalist account

4. Activist media / blogger / citizen journalist

5. Jeremy Corbyn

6. Labour Party MP / Labour Party Councillor

7. Accounts affiliated to the Labour Party

8. MP from another political party

9. Account affiliated to other political parties

10. Celebrity (arts; music; sports etc.)

11. Government account or policymaker

12. Momentum supporter / local group

13. Momentum

14. Other campaigner / campaigning organisation

15. Other

16. Unclear

(C) Function of post

1. Asking members and supporters to complete a specific task

2. Collecting member feedback on issues

3. Organising an event or a protest action

4. Sharing news coverage

5. Sharing a petition

6. Sharing party political communication (e.g. manifesto video)

7. Reference to a specific Momentum tool (e.g. My Nearest Marginal; M.App)

8. Amplifying supporter expression / action

9. Sharing campaign from other political organisation

10. Sharing information about past Momentum success/campaign

11. Updates from a Momentum event, or an event that Momentum were involved in

12. Expressing opinion on behalf of Momentum

13. Other

14. Unclear

(D) Topic of post

1. Healthcare 
2. Education

3. Economy and austerity

4. Sex and LGBTQ Issues

5. Anti-Semitism / Israel Palestine conflict

6. Donald Trump and US politics

7. Brexit and the European Union

8. Grenfell

9. Conduct of politicians

10. Discussion of political ideology (e.g. Marxism; Capitalism)

11. Media criticism and media coverage

12. Polls

13. Alt-Right issues / Far right

14. The Labour Party: Deselections

15. The Labour Party: Internal elections

16. The Labour Party: Blairite / Centrist discussion

17. The Labour Party: Role of Momentum and other affiliated groups to Labour in party

18. The Labour Party: Policy

19. The Labour Party: Other

20. Momentum: Internal elections of Momentum

21. Momentum: Local group meetings

22. Momentum: Other

23. Conservative Party

24. Any other political party in the UK

25. Theresa May

26. Local politics

27. Sports

28. Entertainment, arts and culture

29. Crime

30. Environment

31. Public ownership

32. Immigration

33. International affairs

34. Other

35. Unclear

(E) Contains an Emoji?

Yes

No

(F) Features a video produced by Momentum?

Yes

No

Twitter

(A) Type of Tweet

1. Tweet 
2. Commented Retweet

3. Retweet

4. Reply

5. Unclear

(B) If RT - type of actor

1. Member of the public

2. News media corporate account

3. News media personal/journalist account

4. Activist media / blogger / citizen journalist

5. Jeremy Corbyn

6. Labour Party MP / Labour Party Councillor

7. Accounts affiliated to the Labour Party

8. MP from another political party

9. Account affiliated to other political parties

10. Celebrity (arts; music; sports etc.)

11. Government account or policymaker

12. Momentum supporter / local group

13. Momentum

14. Other campaigner / campaigning organisation

15. Other

16. Unclear

(C) Function of post

1. Asking members and supporters to complete a specific task

2. Collecting member feedback on issues

3. Organising an event or a protest action

4. Sharing news coverage

5. Sharing a petition

6. Sharing party political communication (e.g. manifesto video)

7. Reference to a specific Momentum tool (e.g. My Nearest Marginal; M.App)

8. Amplifying supporter expression / action

9. Sharing campaign from other political organisation

10. Sharing information about past Momentum success/campaign

11. Updates from a Momentum event, or an event that Momentum were involved in

12. Expressing opinion on behalf of Momentum

13. Other

14. Unclear

(D) Topic of post

1. Healthcare

2. Education

3. Economy and austerity

4. Sex and LGBTQ Issues

5. Anti-Semitism / Israel Palestine conflict

6. Donald Trump and US politics

7. Brexit and the European Union 


\section{Grenfell}

9. Conduct of politicians

10. Discussion of political ideology (e.g. Marxism; Capitalism)

11. Media criticism and media coverage

12. Polls

13. Alt-Right issues / Far right

14. The Labour Party: Deselections

15. The Labour Party: Internal elections

16. The Labour Party: Blairite / Centrist discussion

17. The Labour Party: Role of Momentum and other affiliated groups to Labour in party

18. The Labour Party: Policy

19. The Labour Party: Other

20. Momentum: Internal elections of Momentum

21. Momentum: Local group meetings

22. Momentum: Other

23. Conservative Party

24. Any other political party in the UK

25. Theresa May

26. Local politics

27. Sports

28. Entertainment, arts and culture

29. Crime

30. Environment

31. Public ownership

32. Immigration

33. International affairs

34. Other

35. Unclear

(E) Contains an Emoji?

Yes

No

(F) Features a video produced by Momentum?

Yes

No

\footnotetext{
${ }^{1}$ A supporter of Momentum is defined by those who sign up to be message recipient of the group's communications over email or social media. To become a member, one must declare that they are a Labour Party member and pay a subscription fee, varying depending on earnings.

${ }^{2}$ Outside of social media, it is important to note that other digital tools are significant when evaluating how political organisations engage with supporters. As Dommett and Temple (2018), McDowell-Naylor (2019), and Rhodes (2019) show, applications developed by Momentum have significant implications for the literature on digital campaigning. During the 2017 UK general election, over 100,000 people used the My Nearest Marginal application (Rees, 2017). This enabled users to identify nearby marginal seats and offer travel assistance to those willing to canvass in these strategically important constituencies. Furthermore, on the day of the election, supporters were encouraged to use WhatsApp to mobilise voters, with around 400,000 people receiving messages on polling day asking them to support the Labour leader (Rhodes, 2019).
} 
${ }^{3}$ Six interviews were conducted with supporters who were not involved with the Portsmouth group. These participants provided insights on the national-level social media accounts but were not asked about local-level organising.

${ }^{4} \mathrm{~A}$ longstanding parliamentary convention in which an MP who cannot physically be in the House of Commons as a result of illness or maternity leave is paired with a colleague to cancel out their vote.

${ }^{5}$ This does not necessarily mean that Momentum fails to offer digital feedback loops but may instead point to the specific roles that these platforms play within the organisation. Members highlighted email as a mechanism for feedback (Interview 2, Interview 5; July 2018). Furthermore, Momentum has recently launched My.Momentum (https://my.peoplesmomentum.com/), a platform designed to democratize decision-making within the organisation. Todd (Interview 3, July 2018) was the only interviewee to have used it and noted that while it enabled members to vote on leader-directed consultations, this was a drop-down list with no free-text option to recommend or discuss strategy.

${ }^{6}$ Communication within the Facebook Group was not included in this study due to the ethical concerns of analysing the private communication of citizen activists (see Williams et al. 2017). 